\title{
Опыт применения инактивированной вакцины против вирусного гепатита утят типа I
}

Никитина Н.В., кандидат биологических наук, доцент, ведущий научный сотрудник отдела вирусологии Трубицын М.М., младший научный сотрудник отдела вирусологии Всероссийский научно-исследовательский ветеринарный институт птицеводства (ВНИВИП) - филиал ФГБНУ ФНЦ «Всероссийский научно-исследовательский и технологический институт птицеводства» РАН

\begin{abstract}
Аннотац,ия: Вирусный гепатит утят типа I (ВГУ-1) широко распространен бо бсем мире и наносит значительный экономический ущерб уткободческим хозяйствам. Оснобной мерой защиты от болезни и ограничения ее распространения ябляется Вакцинопрофилактика. В работе представлень результаты изучения сбойств и эфрективности инактивированной бакцины против ВГУ-1 6 произбодственных условиях. Показано, что инактивированная бакцина с эмульсией обратного типа, полученная на основе отечественного масляного адьюбанта, стабильна, безбредна для уток и обладает бысокими антигенными и иммуногенными сбойствами, обеспечибает эффективную трансовариальную передачу материнских антител к утятам от однократно бакцинированных матерей. Данная бакцина может быть рекомендована для специфической профилактики ВГУ- 1 в утководческих хозяйствах.
\end{abstract}

Ключебые слова: Вирусный гепатит утят типа І, вакцина, сыворотка крови, специфические антитела.

Введение. Вирусный гепатит утят типа І (ВГУ-1) является высоко контагиозной и быстро распространяющейся инфекцией молодых утят, в основном, до 4-6-недельного возраста. Болезнь протекает с преимущественным поражением печени и высокой смертностью молодняка - до 95\% [1-3], что наносит значительный экономический ущерб утководческим хозяйствам [4,5].

Контроль над заболеванием в настоящее время основан на использовании аттенуированной вирусвакцины ВНИИзЖ, которой вакцинируют утят однодневного возраста, чтобы получить активный иммунитет, или уток-несушек, с целью передачи материнских антител потомству, а также при изолированном выращивании молодняка $[6,7]$.

За рубежом для обеспечения стойкого эпизоотического благо- получия по ВГУ-1 применяются как живые, так и инактивированные вакцины, что обеспечивает создание напряженного и продолжительного иммунного ответа. Инактивированную вакцину применяют при иммунизации ремонтного молодняка уток или при его переводе в родительское стадо за месяц перед началом яйцекладки, с целью получения утят, устойчивых к заражению полевым вирусом в течение восприимчивого периода [8].

В предыдущие годы во ВНИВИП для разработки отечественной инактивированной вакцины против ВГУ-1 были проведены исследования по подбору производственного штамма вируса, отработаны методы изготовления вакцины и ее компонентный состав. Опытные образцы вакцины прошли лабораторные испытания. Результаты исследований показали, что инактивированная вакцина против ВГУ-1 обладает выраженными и продолжительными антигенными свойствами в течение 9 месяцев (срок наблюдения).

Целью настоящих исследований явилось изучение эффективности опытной серии инактивированной вакцины против ВГУ-1 в производственных условиях.

Материал и методика исследований. В качестве производственного штамма использовали «Штамм «ВН-3» вируса гепатита утят типа I рода Avihepatovirus семейства Picornaviridae для производства вакцинных препаратов и диагностических наборов» (патент RU 267599) [9]. Его культивировали и титровали на 11-12-суточных утиных эмбрионах из благополучного по инфекционным болезням фермерского хозяйства. Эмбрионы за- 
ражали в аллантоисную полость оттитрованным вирусом в дозе 3,0 lg ЭЛД ${ }_{50} / 0,2$ см $^{3}$. Инфицированные и контрольные эмбрионы инкубировали при температуре $37,0 \pm 0,5^{\circ} \mathrm{C}$ и относительной влажности 60-70\%, ежедневно овоскопируя в течение 96 ч. Вируссодержащий материал, собранный от эмбрионов, погибших через 72-96 ч инкубации, после гомогенизирования и 3-кратного замораживания и оттаивания центрифугировали при 3000 об./мин в течение 30 мин. В надосадочной жидкости определяли биологическую активность вируса титрованием десятикратных разведений вируссодержащего материала на утиных эмбрионах. Величину титра вычисляли методом Рида-Мюнха (1938) и выражали в Ig ЭЛД ${ }_{50} / \mathrm{cm}^{3}$.

Вирус инактивировали биоцидом «Инак» (ЗАО «Петрохим», Россия) В конечной концентрации $0,1 \%$ в режиме постоянного перемешивания в течение 24 ч при температуре $37,0 \pm 0,5^{\circ} \mathrm{C}$. По окончании инактивации остаточное количество биоцида «Инак» нейтрализовали 2М раствором тиосульфата натрия до конечной концентрации 0,03 М. Полноту инактивации вируса проверяли методом трехкратных пассажей на утиных эмбрионах, которым тестируемый материал вводили в аллантоисную полость в объеме 0,2 см³ $^{3}$. Отсутствие в течение 5 суток инкубации характерных для вируса гепатита утят изменений в эмбрионах и их гибели подтверждало его авирулентность.

При изготовлении инактивированной эмульгированной вакцины использовали масляный адъювант АБ-М4 (В/М) (ЗАО «Петрохим», Россия). Его смешивали с инактивированным антигеном В соотношении 70:30 на гомогенизаторе в течение 5-10 мин при скорости вращения винта 3000 об./мин и температуре $10^{\circ} \mathrm{C}$.

Качество вакцины контролировали определением физикохимических (стабильности и кинематической вязкости эмульсии) и иммунобиологических (стерильности, безвредности, антигенной и иммуногенной активности) свойств.

\section{Оиенка физико-химиче-} ских сбойств бакииньл. Вакцину считали хорошего качества, если после испытаний стабильности эмульсии при ее хранении при температуре $37,0 \pm 0,5^{\circ} \mathrm{C}$ в течение 14 суток, а также при центрифугировании при 3000 об./ мин в течение 30 мин, в процессе визуального контроля не было обнаружено никаких изменений содержимого во флаконе. Высота столба прозрачной фракции, сформировавшейся в верхней части флакона, не должна превышать $10 \%$ от общей высоты столба эмульсии. Кинематическая вязкость вакцинной эмульсии не

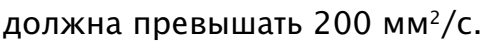

Стерильность и контаминацию Ваки,ины бактериями, грибами и микоплазмами определяли по ГОСТ 280852013. Высевы делали на МПБ, МПА, МППБ под вазелиновым маслом и на агар Сабуро. Посевы выдерживали при $37^{\circ} \mathrm{C}$ в течение 10 суток, а на агаре Сабуро при $18-24^{\circ} \mathrm{C}$ в течение 14 суток. Контроль на контаминацию вакцины микоплазмами проводили методом ПЦР.

Ои,нка безВредности Ваки,ины. Безвредность вакцины устанавливали визуально по степени поражения тканей в месте введения вакцины уткам в прививочной и в 5 раз более высокой дозе через 21 сутки после иммунизации, по критериям, предложенным Г. Стоуном [10].

Антигенную активность вакцины оценивали путем определения уровня специфических антител в сыворотке крови контрольных и вакцинированных уток методом иммуноферментного анализа (ИФА) [1 1 ].

Иммуногенность вакцины оценивали по уровню трансовариальных антител в ИФА в сыворотке крови суточных утят, полученных от иммунизированных уток.

Испытания вакцины проводили на взрослом поголовье уток в фермерском хозяйстве КФХ «Левин» Волосовского района Ленинградской области. Хозяйство благополучно по острым инфекционным болезням, в том числе и по ВГУ-1.

Уток вакцинировали инактивированной эмульгированной вакциной согласно временной инструкции по применению препарата, утвержденной директором ФНЦ «ВНИТИП» РАН.

У взрослых уток перед вакцинацией и через 14, 28 и 60 суток после вакцинации брали кровь и получали сыворотку крови для определения титра специфических антител методом ИФА согласно Методическим положениям «Определение специфических антител к вирусу гепатита утят типа I методом иммуноферментного анализа» (2018).

Полученные данные подвергали статистическому анализу с использованием критерия Стьюдента, считая их достоверными при $\mathrm{p}<0,05$.

Результаты исследований и их обсуждение. Вируссодер- 
жащий материал, полученный на 11-12-суточных утиных эмбрионах, имел биологическую актив-

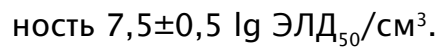

При обработке вируссодержащего материала биоцидом «Инак» и проверке полноты инактивации вируса методом трехкратных пассажей на утиных эмбрионах установлено, что вирус полностью потерял инфекционную активность.

При определении физико-химических свойств вакцины установлено, что вакцина при световой микроскопии имеет мелкозернистую равномерную структуру эмульсии (индекс гомогенности составил 0,94). Вязкость эмульсии соответствовала критерию качественности (менее 200 мм² $^{2}$ ).

В тестах центрифугирования и «быстрого старения» эмульгированная вакцина оставалась стабильной: величина верхней фракции составляла 1,5\%, отслоения водной фазы не отмечалось. «Капельный метод» показал, что препарат представлял собой «обратный» тип эмульсии.

Таким образом, инактивированная эмульгированная вакцина против ВГУ-1 имела высокую стабильность эмульсии, низкую вязкость и высокую гомогенность дисперсной фазы.

Высевы образцов инактивированной вакцины были свободны от контаминации бактериями, грибами и микоплазмами, что свидетельствовало об их стерильности.

Динамика показателей среднего геометрического титра антител к ВГУ-1 в ИФА представлена в табл. 1. Как показывают эти данные, вакцина индуцировала у однократно привитых уток интенсивный иммунный ответ через 14 , 28 и 60 суток после вакцинации.

\begin{tabular}{|c|c|c|c|}
\hline \multirow{3}{*}{ Группы } & \multicolumn{3}{|c|}{ Титры антител в ИФА (обратные значения) } \\
\hline & \multicolumn{3}{|c|}{ Сроки после вакцинации, сут. } \\
\hline & 14 & 28 & 60 \\
\hline Вакцинированные утки & $2165 \pm 115$ & $4892 \pm 155$ & $8532 \pm 215$ \\
\hline Невакцинированные утки & $418 \pm 15$ & $418 \pm 15$ & $418 \pm 15$ \\
\hline
\end{tabular}

У суточных утят ( $n=10)$, полученных от вакцинированных уток на 60 сутки после вакцинации, средний титр материнских антител в сыворотке крови в ИФА составил 5032 \pm 125 , при их 100\% передаче. Сыворотка крови суточных утят, полученных от невакцинированных уток, антител не содержала.

В области подкожного введения вакцины уткам воспалительная реакция отсутствовала. Клинических отклонений в состоянии здоровья птицы не зарегистрировано, что указывает на безвредность препарата.

Данные свидетельствуют о том, что инактивированная вакцина вызывает иммунологическую перестройку в организме уток, индуцируя образование специфических антител в высоких титрах. Трансовариальная передача материнских антител обеспечивала устойчивость утят к инфекции в процессе выращивания.

Заключение. Результаты исследования показали, что инактивированная эмульгированная вакцина стабильна, иммуногенна, безвредна и может быть рекомендована для специфической профилактики ВГУ-1 в утководческих хозяйствах.

\section{Литература}

1. Трефилов, Б.Б. Вирусный гепатит утят типа I (эпизоотология, патогенез и диагностика) / Б.Б. Трефилов, Н.В. Никитина, К.Ю. Дмитриев, М.М. Тру- бицын // Эффективное животноводство. - 2017. - №3. - С. 12-13.

2. Обухов, М.Н. Вирусный гепатит утят. / М.Н. Обухов, А.И. Господинова // Актуальные проблемы и методические подходы к диагностике, лечению и профилактике болезней животных и птиц: Мат. междунар. науч.практ. конф. - Пос. Персиановский, 2021. - С. 113-116.

3. Бубашко, О.А. Вирусный гепатит утят в Республике Беларусь и его профилактика // Эпизоотология, иммунология, фармакология и санитария. 2005. - №1 . - C. 25- 28.

4. Lin, S.L. Circulation and in vivo distribution of duck hepatitis A virus types 1 and 3 in infected ducklings / S.L. Lin, R.C. Cong, R.H. Zhang [et al.] // Arch. Virol. - 2016. - V. 161. - P. 405-416.

5. Chen, L.L. Improved duplex RP$C R$ assay for differential diagnosis of mixed infection of duck hepatitis $A$ virus type 1 and type 3 in ducklings / L.L. Chen, Q. Xu, R.H. Zhang [et al.] // J. Virol. Meth. - 2013. -V. 192. - P.12-17. 6. Фоменко, В.Ю. Профилактика вирусного гепатита утят / В.Ю. Фоменко, А.А. Чеснокова, В.С. Волков // Научное обеспечение животноводства Сибири: Мат. IV Междунар. науч.-практ. конф. - Красноярск, 2020. - С. 460464.

7. Князев, В.П. Болезни водоплавающих птиц. - Владимир: ВНИИзЖ, 2013. - 325 c.

8. Yin, F. Development and evaluation of an inactivated bivalent vaccine against duck viral hepatitis / F. Yin, J. Li, S. Zhang, [et. al] // Chinese J. Biotechnol. - 2015. V. 31, No 11. - P.1579-1588. 
9. Патент RU 2675995. Штамм «ВН-3» вируса гепатита утят типа I рода Avihepatovirus семейства Picornaviridae для производства вакцинных препаратов и диагностических наборов / Трефилов Б.Б., Никитина Н.В., Явдошак Л.И., Трубицын M.M. - 2018.
10. Stone, H.D. Newcastle disease oilemulsion vaccines prepared with animal, vegetable and synthetic oils // Avian Dis. - 1997. - V. 41. - P. 591-597. 1 1. Патент RU 2684417. Способ определения специфических антител к вирусу гепатита утят типа I / Никитина Н.В., Трефилов Б.Б., Дмитриев К.Ю. - 2018.
Для контакта с авторами:

Никитина Нина Васильевна

E-mail:

vnivip.nikitina@yandex.ru

Трубицын

Михаил Михайлович

E-mail:

hawx_93@mail.ru

\title{
Experimental Test of an Inactivated Vaccine against Duck Viral Hepatitis A Type 1
}

\author{
Nikitina N.V., Trubitsyn M.M. \\ Federal Scientific Center "All-Russian Research and Technological Institute of Poultry" \\ of Russian Academy of Sciences
}

Summary: Duck viral hepatitis A type I (DVH-1) is a highly lethal, contagious and rapidly spreading infection of young ducklings resulting in significant financial losses to duck farms. The specific prophylaxis of the disease plays an important role in its on-farm prevention and elimination. The experimental batch of an inactivated emulsified vaccine (reversed emulsion produced with the use of Russian oil adjuvant) was experimentally tested; physical (viscosity, stability) and biological (antigenicity, immunogenicity) properties were tested. It was found that the vaccine is stable and non-harmful for the ducks; it generated high and stable antibody levels in blood serum of the ducks during 14-60 days after the vaccination and provided the effective transovarian transfer of maternal antibodies to the ducklings. The conclusion was made that the inactivated vaccine can be effectively used for specific prophylaxis of DVH-1 on the duck farms.

Keywords: duck viral hepatitis A type I, vaccine, blood serum, specific antibodies. 